\title{
Activated platelets inhibit hepatocellular carcinoma cell differentiation and promote tumor progression via platelet-tumor cell binding
}

\author{
Rongfeng Zhang ${ }^{1, *}$, Huishu Guo ${ }^{2, *}$, Jingchao $\mathrm{Xu}^{3}$, Bing Li ${ }^{4}$, Yue-Jian Liu ${ }^{2}$, Cheng \\ Cheng ${ }^{5}$, Chunyan Zhou ${ }^{6}$, Yongfu Zhao ${ }^{3}$, Yang Liu ${ }^{1}$ \\ ${ }^{1}$ Institute of Heart and Vascular Diseases, First Affiliated Hospital of Dalian Medical University, Dalian, China \\ ${ }^{2}$ Department of Central Laboratory, First Affiliated Hospital of Dalian Medical University, Dalian, China \\ ${ }^{3}$ Department of General Surgery, Second Affiliated Hospital of Dalian Medical University, Dalian, China \\ ${ }^{4}$ Department of Clinical Laboratory, First Affiliated Hospital of Dalian Medical University, Dalian, China \\ ${ }^{5}$ Translational Research on Neurological Diseases Center, First Affiliated Hospital of Dalian Medical University, Dalian, China \\ ${ }^{6}$ Department of Clinical Pharmacy, First Affiliated Hospital of Dalian Medical University, Dalian, China \\ *These authors have contributed equally to this work \\ Correspondence to: Yang Liu, email: liuyang19831119@163.com \\ Yongfu Zhao, email: dl.zyf67@163.com
}

Keywords: platelet, clopidogrel, tumor differentiation, hepatocellular carcinoma, TCF4

Received: January 17, 2016

Accepted: July 26, 2016

Published: August 16, 2016

\section{ABSTRACT}

Lack of differentiation in hepatocellular carcinoma (HCC) is associated with increased circulating platelet size. We measured platelet activation and plasma adenosine diphosphate (ADP) levels in HCC patients based on differentiation status. Local platelet accumulation and platelet-hepatoma cell binding were measured using immunohistochemistry (IHC) or flow cytometry. Using a xenograft assay in NON/SCID mice, we tested the effects of the anti-platelet drug clopidogrel on platelet activation, platelet infiltration, platelet-tumor cell binding and tumor cell differentiation. HCC patients with poor differentiation status displayed elevated platelet activation and higher ADP levels. Platelets accumulated within poorly differentiated tissues and localized at hepatoma cell membranes. Platelet-tumor cell binding was existed in carcinoma tissues, largely mediated by P-selectin on platelets. NOD/SCID mice with xenograft tumors also exhibited increased platelet activation and platelet-tumor cell binding. Clopidogrel therapy triggered hepatoma cell differentiation by attenuating platelet activation and platelet-tumor cell binding. TCF4 knockdown promoted HepG2 cell differentiation and inhibited tumor formation, and TCF 4 could be the potential downstream target for clopidogrel therapy.

\section{INTRODUCTION}

Hepatocellular carcinoma (HCC) is a major cause of cancer-related mortality worldwide [1]. Surgery is the primary intervention for early-stage $\mathrm{HCC}$, but recurrence and metastasis rates are still very high in five years postsurgery [2]. Degree of differentiation is widely accepted as an important prognostic indicator of metastasis, recurrence and chemotherapy resistance in solid tumors, including HCC [3-6]. In clinical practice, more than $50 \%$ of HCCs are pathologically diagnosed as moderately or poorly differentiated carcinomas $[7,8]$.
Portal vein thrombosis (PVT) is a severe complication in HCC. Up to $40 \%$ of HCC patients have PVT at the time of diagnosis [9], and are more likely to experience metastasis and shortened survival compared to patients without PVT [10-12]. This indicates that platelets are hyperactivated in HCC. Increased platelet activation has been reported in HCC, pancreatic adenocarcinoma, gastric cancer and colon cancer, and is associated with increased tumornode-metastasis (TNM) stage and risk of recurrence [1316]. Activated platelets are reportedly involved in critical steps in cancer progression, including facilitating tumor cell growth and migration within vasculature [17]. 
Circulating platelets are heterogeneous in size, density and reactivity [18-20]. Large platelets are hyperactive in function, express high levels of membrane proteins, contain greater number of dense granules, release a large amount of adenosine diphosphate (ADP), and are more resistant to anti-platelet drugs [18, 19, 21]. Thus, mean platelet volume (MPV, a measurement of platelet size) and the proportion of large platelets are important hematological parameters that reflect platelet activation. In our preliminary retrospective study, we found that MPV and the proportion of large platelets in patients with poorly differentiated HCC were higher than in patients with well-differentiated tumors. We studied whether the anti-platelet drug, clopidogrel, could act as anti-cancer therapeutics by promoting tumor cell differentiation, independent of thrombus formation. We reported that tumor tissue-accumulated platelets induced platelet-tumor cell binding and inhibited tumor cell differentiation. Clopidogrel suppressed platelet-tumor cell binding and induced hepatoma cell differentiation in the xenograft model. These findings revealed the efficacy of anti-platelet drugs in HCC treatment.

\section{RESULTS}

\section{Elevated platelet activation and circulating ADP levels in relation to $\mathrm{HCC}$ differentiation status}

Hematological parameters were determined in HCC tissue samples and patients were grouped by differentiation status. Patients with well and moderately differentiated tumors were older than those with poorly differentiated tumors (Table 1). Platelet count had no differences among the three groups, while MPV, platelet distribution width (PDW) and the proportion of large platelets were considerably greater in the moderately and poorly differentiated groups (Figure 1A-1D, Table 1). Patients with moderate and poor differentiation displayed high percentages of $\mathrm{P}$-selectin positive platelets compared to those with well differentiated tumors or healthy controls (Figure 1E). Plasma levels of ADP in moderately/poorly differentiated patients increased by 2-fold compared with the other two groups (Figure 1F).

\section{Platelet accumulation within HCC tissues}

Immunohistochemistry (IHC) revealed platelets $\left(\mathrm{CD} 41^{+}\right)$accumulated in $\mathrm{HCC}$ tissues (Figure 2A$2 \mathrm{H})$. Poorly differentiated tissues displayed prominent platelet accumulation, while staining was reduced in well-differentiated tissues (Figure 2A-2C). In poorly differentiated tissues, platelets were largely found in the hepatoma cell membrane (Figure 2E), intravascular regions (Figure 2G) and connective tissues (Figure 2H). We thus hypothesized that platelets might bind to hepatoma cells.

\section{Platelet-tumor cell binding in tumor tissues and cell culture}

We tested the degree of platelet binding to tumor cells in human HCC tissues and HepG-2 cell culture. Platelet-tumor cell binding increased by $40 \%$ in the poorly/moderately differentiated carcinoma tissues compared with well differentiated tissues (poorly/ moderately: $23.2 \pm 3.4 \%$; well: $15 \pm 2.8 \%$, Figure $3 \mathrm{~A} \& 3 \mathrm{C}$ ). We co-cultured HepG-2 cells with platelets isolated from healthy controls or HCC patients and found that platelets from HCC patients bind more frequently with HepG-2 cells than platelets from healthy controls (HCC patients: $18.7 \pm 1.7 \%$; healthy control: $10.9 \pm 1.9 \%$, Figure $3 \mathrm{~B} \& 3 \mathrm{D})$. In the co-culture system, P-selectin blocking antibody abolished about $50 \%$ of platelet-tumor cell binding (Figure $3 \mathrm{E}$ ), indicating that the binding was largely mediated by P-selectin on platelets.

\section{Anti-platelet intervention abolished tumor cell- evoked platelet activation and induced tumor cell differentiation in the mouse xenograft model}

Similar to patients, mice with HepG-2 cell tumors had elevated P-selectin positive platelets and plasma ADP levels in comparison to healthy controls (Figure 4B $\& 4 C)$. To determine whether platelets were involved in tumor progression, after three weeks of transplantation, mice received clopidogrel treatment for another three weeks. Clopidogrel efficacy was examined by measuring tail bleeding time. Prolonged tail bleeding was observed in the clopidogrel treatment group, indicating that the drug effectively inhibited platelets in our model (Figure 4A). In xenograft tumors, clopidogrel reduced the proportion of P-selectin positive platelets (non-treated: $5.7 \pm 0.4 \%$; clopidogrel-treated: $4.3 \pm 0.5 \%$, Figure $4 \mathrm{~B}$ ), the amount of platelet-tumor cell binding (non-treated: $11.8 \pm 0.8 \%$; clopidogrel-treated: $1.9 \pm 0.2 \%$, Figure 4D) and platelet local infiltration (Figure 4E \& 4F). Clopidogrel treatment inhibited tumor growth from day 15 to day 21 compared with non-treated mice as indicated by tumor volumes (Figure 5A). Anti-platelet treatment induced CK8/CK18 and CK7 expression and reduced vimentin levels (Figure $5 \mathrm{~B})$, indicating that clopidogrel triggered hepatoma cell differentiation. This finding was confirmed by IHC showing that the abundance of heppar-1 (a specific HCC differentiation marker) in the non-treated group was decreased compared with the treatment group (Figure $5 \mathrm{C}-5 \mathrm{E})$.

\section{Microarray analysis in xenograft tumors}

Tumors were isolated from mice ( $n=3$ /group) and gene expression was measured via microarray analysis. A total of 214 genes were differentially expressed between the two groups. We found 140 genes were 
Table 1: HCC patient clinical and hematological parameters by differentiation status

\begin{tabular}{lccc}
\hline & Well differentiated & Moderately differentiated & Poorly differentiated \\
\hline Number & 31 & 29 & 40 \\
Male gender $(\%)$ & 74 & 73 & 90 \\
Age (year) & $58 \pm 10$ & $58 \pm 8$ & $53 \pm 8^{* \dagger}$ \\
Platelet count $\left(10^{9} / \mathrm{L}\right)$ & $160.2 \pm 65.9$ & $133.9 \pm 41.5$ & $132.2 \pm 54.6$ \\
Mean platelet volume (fL) & $10.8 \pm 0.9$ & $11.4 \pm 0.9 *$ & $11.7 \pm 1.4 *$ \\
Platelet distribution width (fL) & $13.0 \pm 2.2$ & $14.1 \pm 2.0^{*}$ & $14.3 \pm 1.9 *$ \\
Large platelet $(\%)$ & $30.9 \pm 7.6$ & $35.2 \pm 6.3 *$ & $36.6 \pm 6.8^{*}$ \\
White blood cell $\left(10^{9} / \mathrm{L}\right)$ & $6.0 \pm 2.6$ & $5.7 \pm 2.4$ & $5.6 \pm 1.74$ \\
Monocyte $\left(10^{9} / \mathrm{L}\right)$ & $0.5 \pm 0.2$ & $0.4 \pm 0.2$ & $0.5 \pm 0.2$ \\
Neutrophil $\left(10^{9} / \mathrm{L}\right)$ & $3.5 \pm 2.4$ & $3.0 \pm 1.9$ & $3.5 \pm 1.9$ \\
Lymphocyte $\left(10^{9} / \mathrm{L}\right)$ & $1.9 \pm 0.7$ & $2.2 \pm 1.8^{*}$ & $1.5 \pm 0.5^{* \dagger}$ \\
\hline
\end{tabular}

Mean \pm SD. $* P<0.05$ vs. well differentiated, $\dagger P<0.05$ vs. moderately differentiated.

A
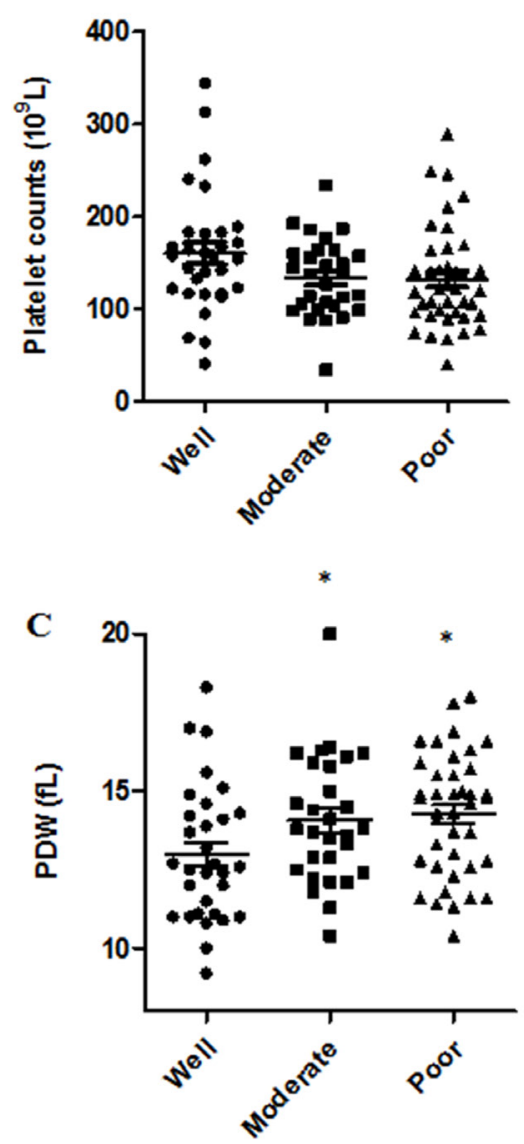

B
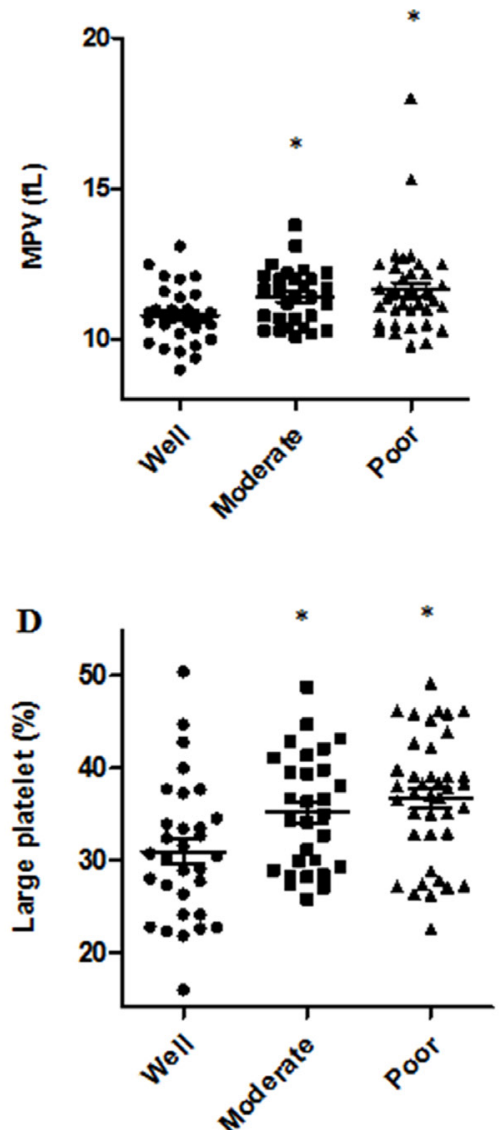

$\mathbf{E}$
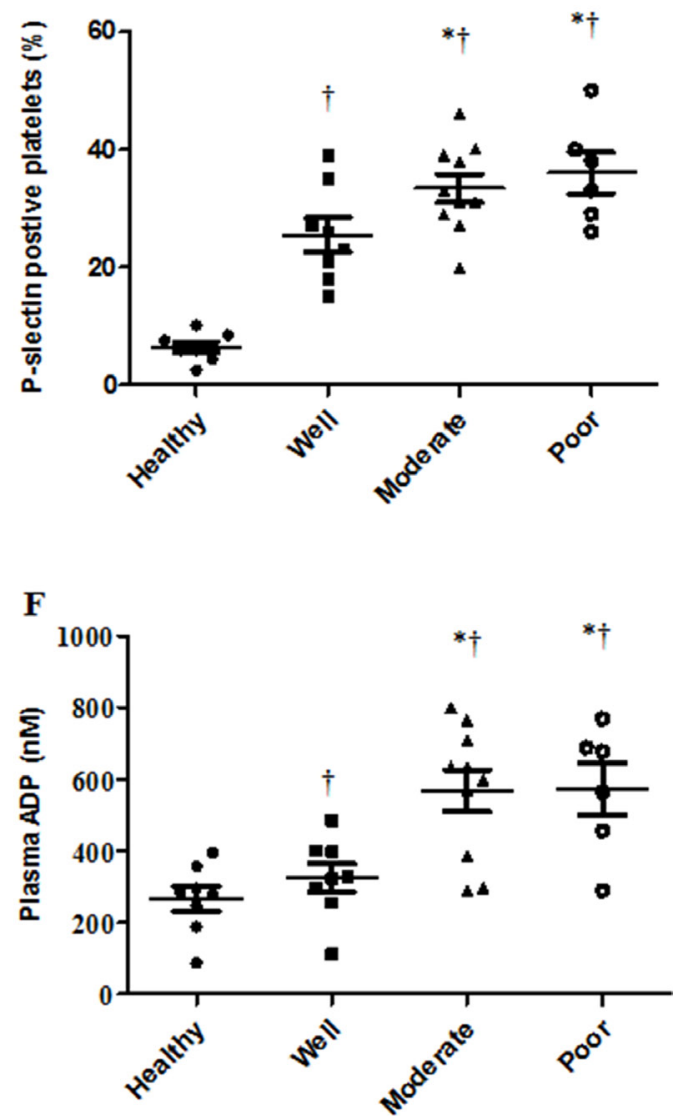

Figure 1: Elevated platelet activation and circulating ADP levels in relation to HCC patient cell differentiation status. HCC patient platelet counts were the same among the three groups A. Increasing MPV B., PDW C. and proportion of large platelets D. was observed in moderately and poorly differentiated compared with well differentiated disease. Patients with poor or moderate differentiation status had more P-selectin positive platelets and elevated ADP plasma levels compared to patients with well differentiated disease or healthy controls $\mathbf{E} \& \mathbf{F}$. $† P<0.05$ vs. healthy controls, ${ }^{*} P<0.05$ vs. well differentiated. 
upregulated and 74 genes were downregulated in the non-treated group compared with the clopidogrel-treated group (Supplementary Table 1). Genes that have been extensively studied in tumor progression were identified and analyzed in a heat map (Figure 6A).

\section{Verification of gene expression by $q$ PCR analysis}

To validate the microarray data, 14 genes including CCAR1, MALAT1, FOXP1, TCF4, PAK2, CUX1, PDGFA, ZNF217, TRRAP, DICER1, P4HB, HSPH1, AKAP2 and $B A C H 1$ were analyzed via qPCR. Fold changes detected by qPCR were comparable with microarray results (Figure 6B).

\section{TCF4 knockdown induced differentiation and decreased tumorigenicity}

To explore whether TCF4 suppression inhibits HepG2 cell proliferation and leads to differentiation, cells were transfected with siTCF4/shTCF4 or control sequences. TCF4 knockdown in HepG2 cells led to marked morphologic changes compared with the control. In the TC4 knockdown group, CK8/18 and CK7 protein levels
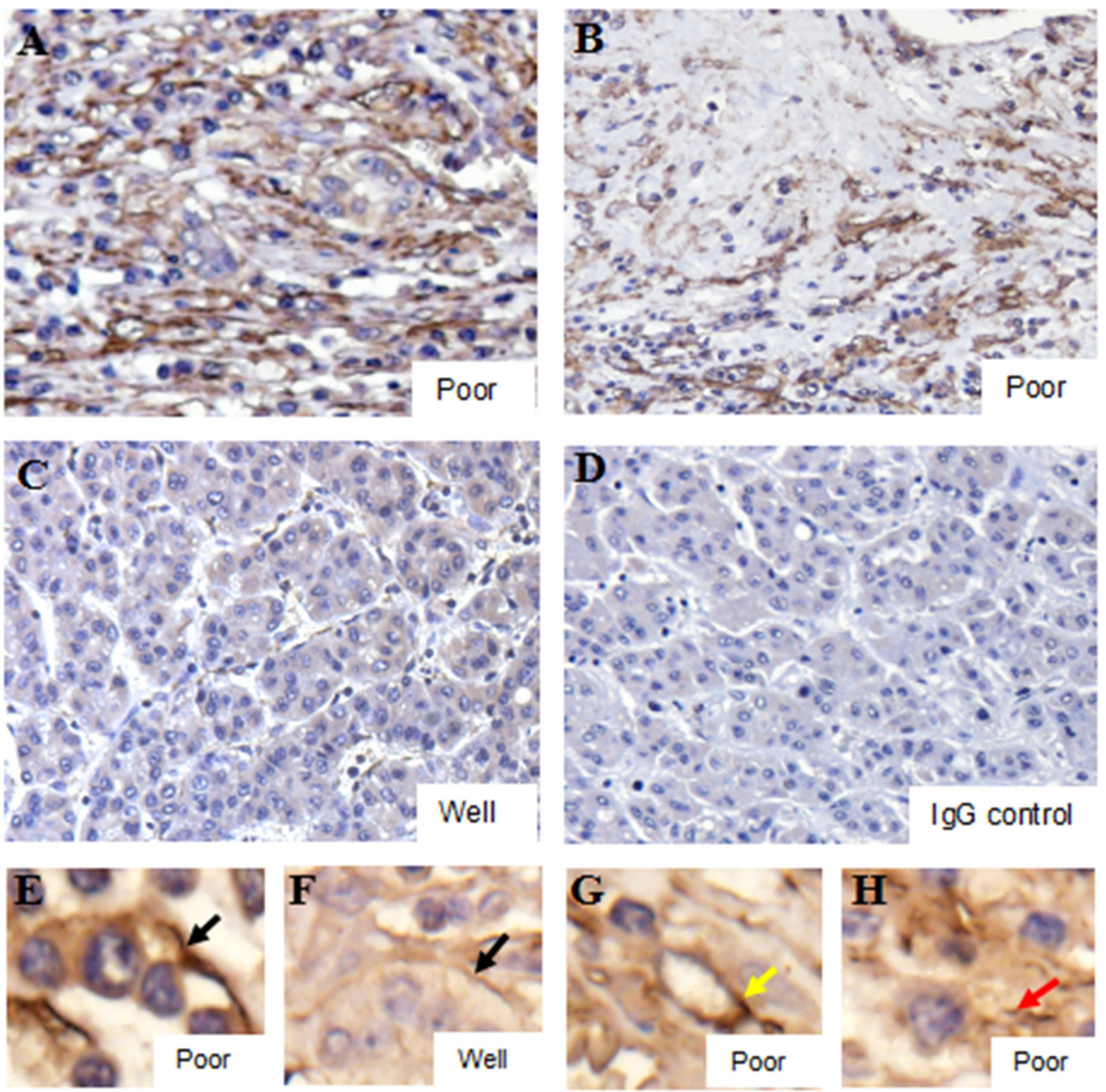

Figure 2: Platelet accumulation within HCC tissues is related to differentiation status. Poorly differentiated tissues displayed prominent IHC platelet staining A \& B., with weak staining in well differentiated tissues C. Black arrows indicated co-localization of platelets and cell membranes $\mathbf{E} \& \mathbf{F}$. Yellow and red arrows indicated platelets in intravascular regions G. and connective tissues H., respectively. The IgG control was shown in $\mathbf{D}$. 
were increased, whereas vimentin level was reduced. Both cell number and colony formation assays showed that TCF4 knockdown inhibited cell growth (Figure 7D-7E), and suppressed the number of Ki67-postive cells (Figure 7F). In vivo, transfected HepG-2 cells exhibited reduced tumorigenicity compared with control cells (Figure 7G). These results suggested that TCF4 knockdown induced HepG-2 cell differentiation and reduced tumorigenicity.

\section{DISCUSSION}

In the present study, we used both clinical data and xenograft assay in NOD/SCID mice to investigate the potential role of platelets in inhibiting hepatoma cell differentiation. Several novel findings have been made. First, an elevation in platelet activation and plasma levels of ADP was found in poor differentiation HCC in comparison to well differentiation. Second, platelets/ platelet-tumor cell binding was observed in HCC tissues, with high levels in poorly differentiated tissues. Third, xenograft tumor induced an elevation in platelet activation and platelet-tumor cell binding in NOD/SCID mice. Fourth, clopidogrel therapy triggered hepatoma cell differentiation, with a marked attenuation of platelet activation and platelet-tumor cell binding as an important mechanism. Fifth, microarrays showed that a total of 214

A
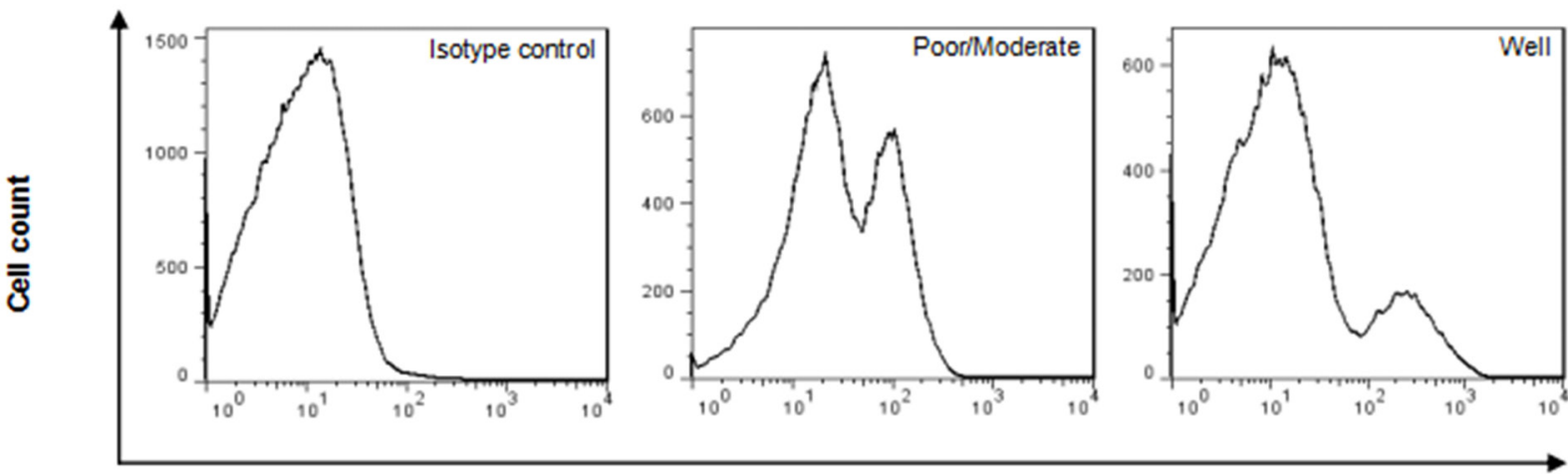

B

FL1-H-CD41
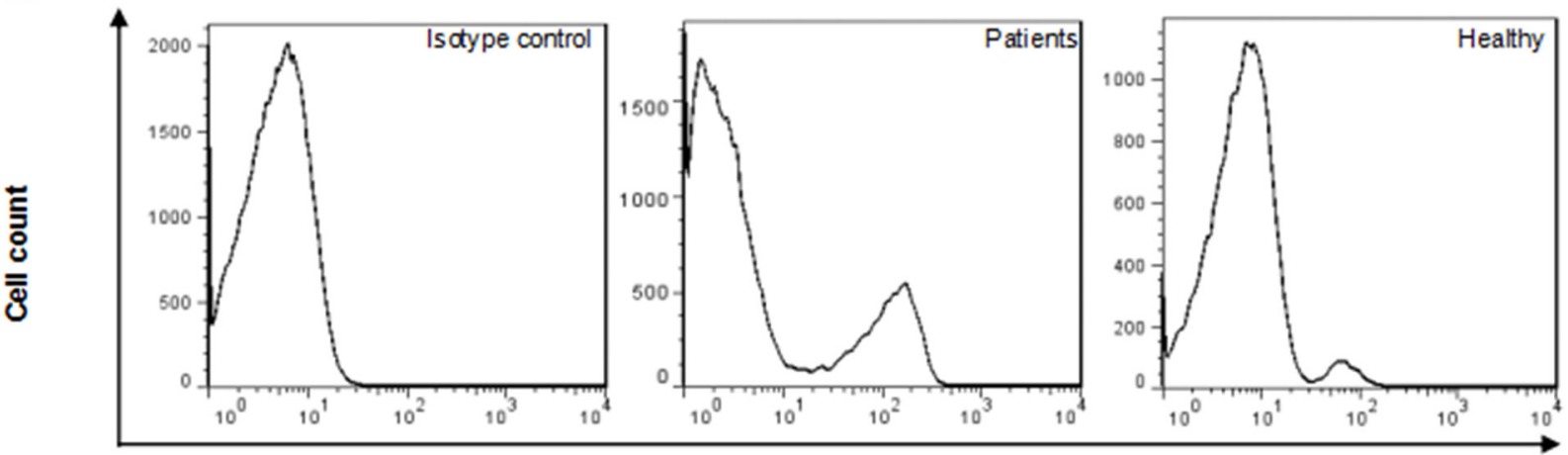

C

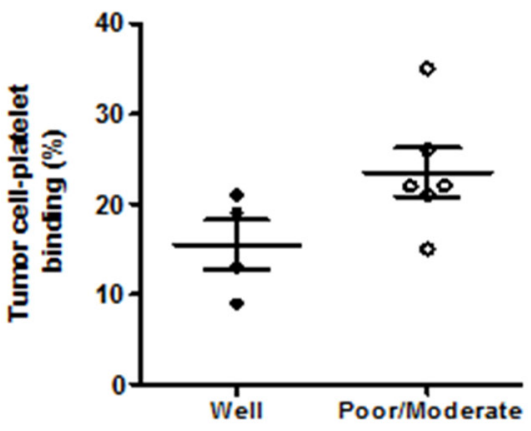

D

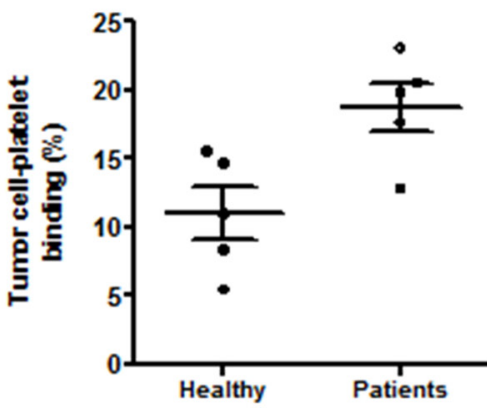

$\mathbf{E}$

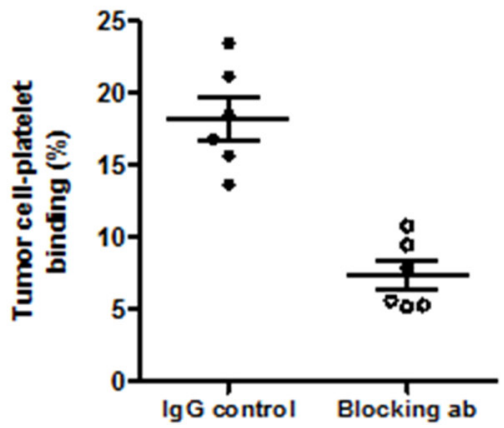

Figure 3: Platelet-tumor cell binding in HCC tissues and cell lines. Representative FACS histogram showing platelet-tumor cell binding as determined by the population of cells expressing platelet marker CD41 in human HCC tissues A. or in HepG-2 cells co-cultured with human platelets $\mathbf{C}$. Quantitative data were presented in panels $\mathbf{B} \& \mathbf{D}$. ${ }^{*} P<0.05, \mathrm{n}=4-6$ /group. 
genes were markedly changed in the tumor tissues after anti-platelet intervention, and we confirmed repression of TCF4 promoted hepatoma cell differentiation.

Platelets have been shown to mediate tumorigenicity via two fundamental mechanisms. First, platelet activation induces granular release of mediators, which directly support tumor growth and migration [22, 23]. Second, platelets can bind to different types of cancer cells, largely mediated by $\mathrm{P}$-selectin on platelets and sialylated fucosylated carbohydrates on tumor cells [24-26]. Such binding protects tumor cells from immune attack or leads to tumor cell metastasis via epithelial-mesenchymal transition (EMT) $[27,28]$. Platelets reportedly bind to breast cancer, melanoma, neuroblastoma, lung cancer, colon cancer and insulinoma cells [24, 27-31]. Consistent with this, we confirmed that HepG-2 cells bind platelets extracted from HCC patients, and less so to platelets from healthy persons, indicating that platelets from HCC patients were more activated. Further, increased platelettumor cell binding was detected in poorly differentiated as compared to well-differentiated HCC tissues, supporting our IHC results showing that platelets largely co-existed on hepatoma cell membranes. We speculated this binding would activate certain intracellular pathways and eventually prevent hepatoma cell differentiation. The hypothesis that platelet-tumor cell binding drives tumor cell escape into vasculature, promoting circulated tumor cells (CTC), requires further investigation.

It remains unclear how platelets are activated in cancer patients. $\mathrm{P} 2 \mathrm{Y}$ receptors, including $\mathrm{P} 2 \mathrm{Y}_{1}$ and $\mathrm{P} 2 \mathrm{Y}_{12}$, are G-protein coupled receptors that control critical steps in platelet activation. ADP initially binds $\mathrm{P} 2 \mathrm{Y}_{1}$ and induces transient activation of platelets, which is subsequently strengthened and sustained by interaction with $\mathrm{P} 2 \mathrm{Y}_{12}[32,33]$. Generation of ADP has been documented in neuroblastoma, breast cancer and melanoma cells, and induces platelet activation [34, 35]. ADP depletion diminished tumor cell-induced platelet activation and was associated with reduced metastasis in mice [36]. In the present study, we demonstrated that plasma ADP levels were increased in HCC patients compared to healthy controls, and were higher in patients
A
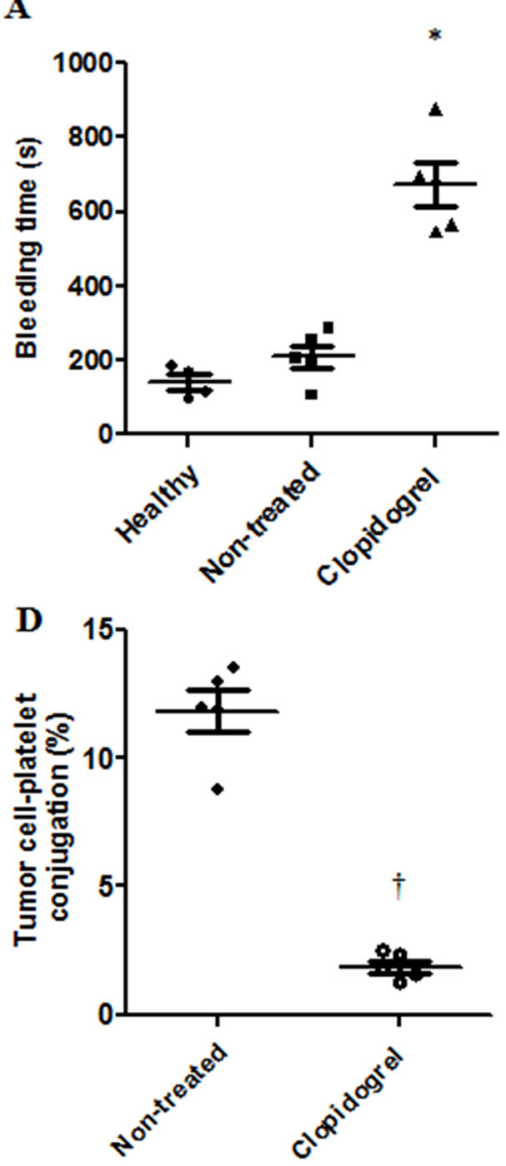

B
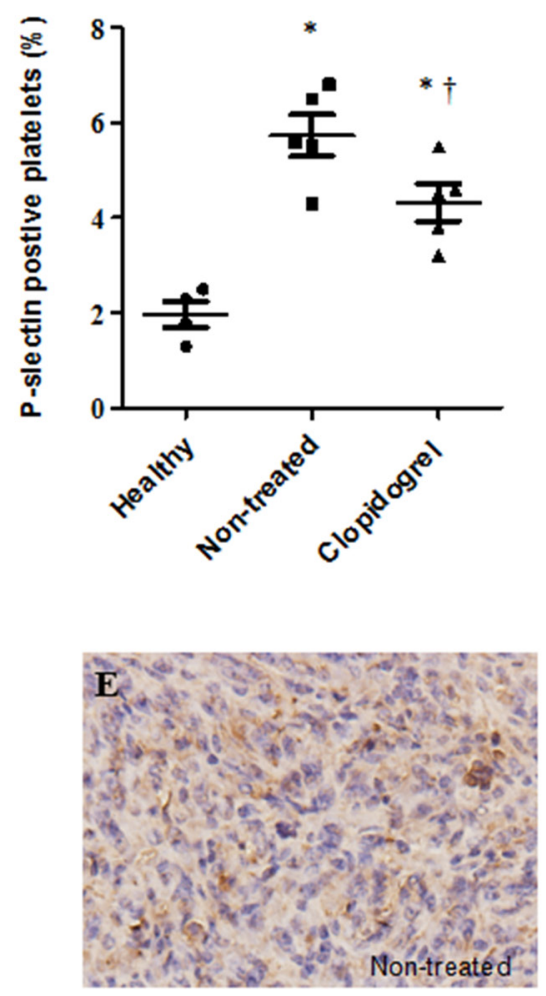

C
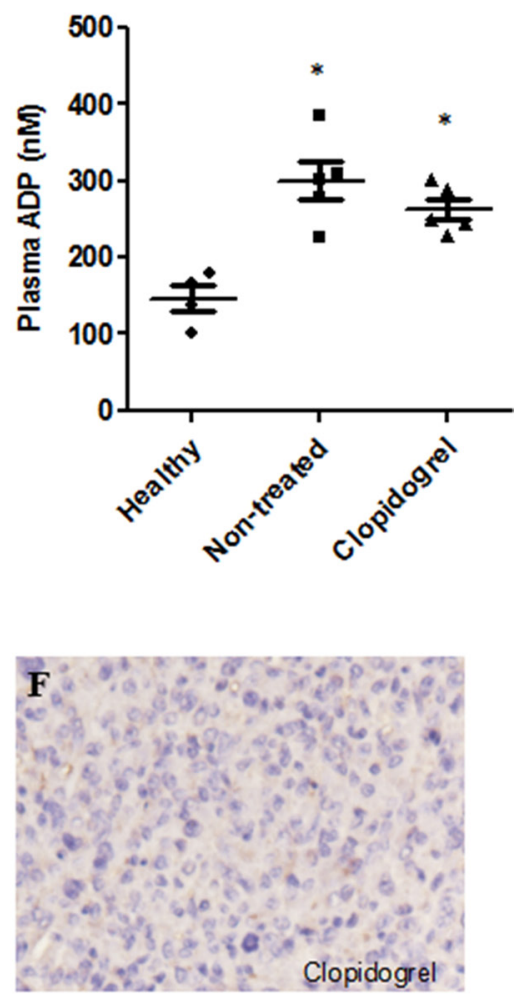

Figure 4: Anti-platelet intervention abolished tumor cell-evoked platelet activation, accumulation and binding in the mouse xenograft model. Mice were injected with HepG-2 cells and one group was treated with clopidogrel. Tail bleeding time was measured in mice with or without treatment A. Increased P-selectin expression by circulating platelets, plasma ADP level and platelettumor cell binding were observed in xenograft mice and were inhibited by clopidogrel treatment B-D. Clopidogrel treatment prevented platelet accumulation in mouse tumor tissues $\mathbf{E} \& \mathbf{F}$. ${ }^{*} P<0.05$ vs. healthy controls, $\uparrow P<0.05$ vs. non-treated, $\mathrm{n}=5 /$ group. 
with well-differentiated compared to moderately or poorly differentiated disease. Similar results were observed in the mouse xenograft tumor model.

Inflammation also causes platelet activation. Most HCC cases are associated with hepatitis B-induced chronic inflammatory responses [37]. In a mouse model of chronic hepatitis B, Sitia, et al. showed that activated platelets contributed to acute hepatocellular injury-induced HCC by enhancing the accumulation of virus-specific CD8 T cells [38]. Clopidogrel combined with aspirin effectively prevented or delayed HCC progression and improved survival.

Tumor thrombosis is a severe cancer complication and forms the rationale for using anti-platelet drugs in cancer therapy. Besides inhibition of thrombus formation, clinical trials have documented broad benefits of antiplatelet drugs. As one of the most commonly used antiplatelet drugs, aspirin has been extensively studied in breast and colorectal cancer, demonstrating positive effects with respect to disease recurrence and patient mortality $[39,40]$. Aspirin in combination with surgical treatment of non-small-cell lung cancer improved patient survival rates [41]. Moreover, aspirin decreased the proangiogenic effect of tamoxifen in breast cancer patients $[42,43]$. In a retrospective analysis of prostate cancer, both aspirin and clopidogrel improved prognosis in patients undergoing radiation [44]. In a murine model, targeting of platelet membrane receptor GPIIb/IIIa, GPIb-IX-V or GPVI reduced pulmonary metastasis [45-49]. Clopidogrel reduced tumor growth and metastasis in a mouse model of pancreatic caner and breast cancer $[50,51]$. In the present study, we demonstrated that clopidogrel treatment at a daily dosage of $5 \mathrm{mg} / \mathrm{kg}$ for three weeks induced tumor cell differentiation and inhibited tumor growth. The treatment in our study was started three weeks post-tumor implantation, and is thus applicable to clinical settings. In our study, we used only clopidogrel, and not aspirin, since clopidogrel was highly specific for platelets. Aspirin inhibits thromboxane A2 (TXA2) production by altering the activity of both cyclooxygenase-1 (COX-1) and COX2 , which are present in platelets, but also in other types of cells, including cancer cells.

A microarray assay was performed to identify potential anti-platelet intervention target candidates in hepatoma cells. A total 214 genes were differentially expressed between treated and non-treated cells, and about 40 genes involved in promoting cancer progression were upregulated in the non-treated group. Some, such

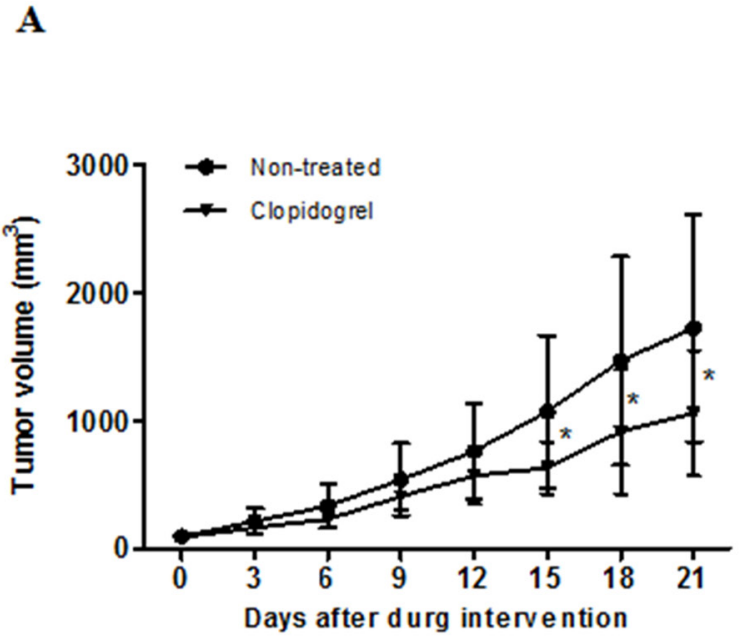

B
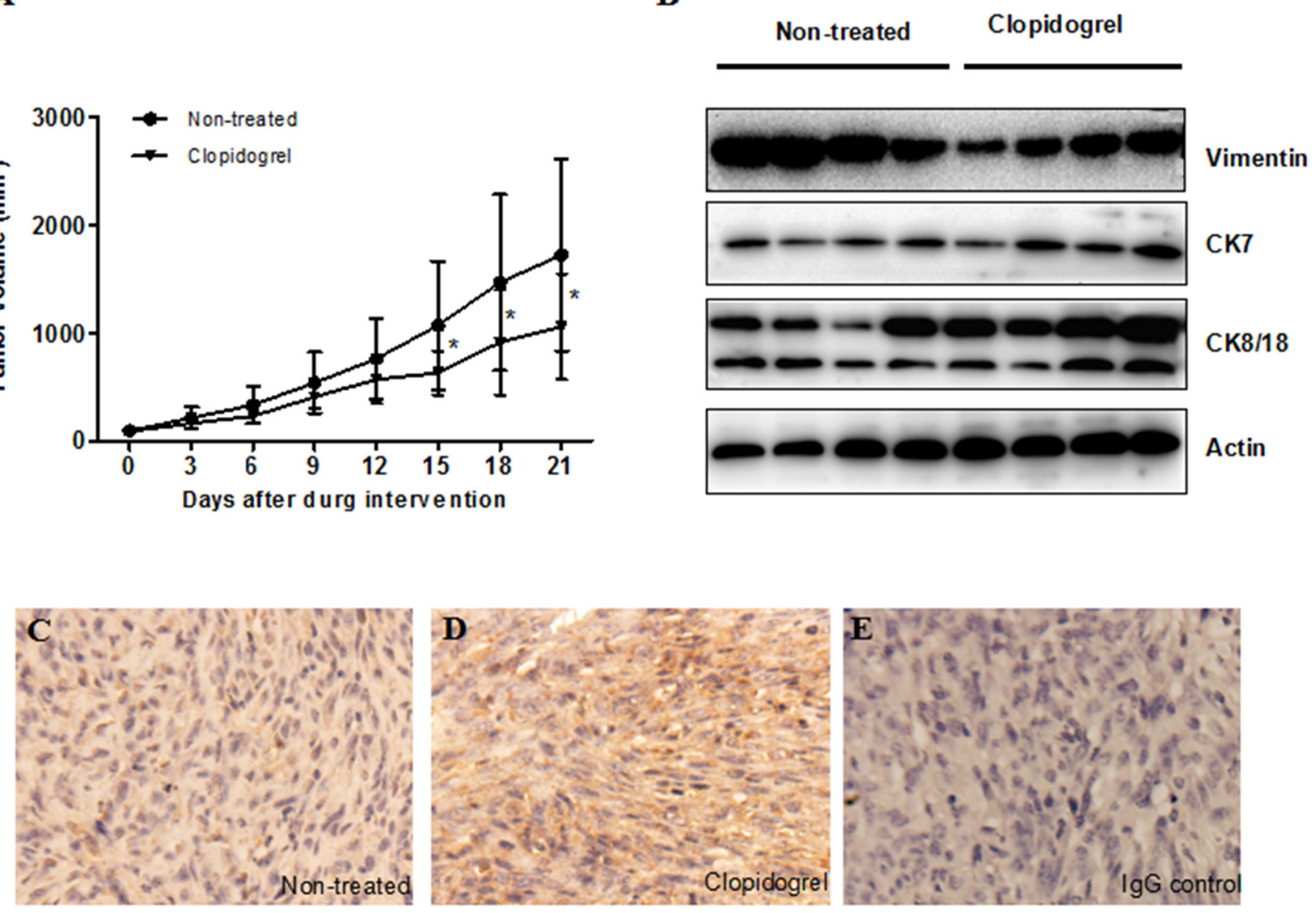

Figure 5: Anti-platelet intervention induced cell differentiation in the mouse xenograft model. Tumor volume was measured every two days in both control and clopidogrel-treated mice A. Differentiation marker expression was analyzed by western blotting B. or IHC C \& D. The IgG control was shown in $\mathbf{E}$. 

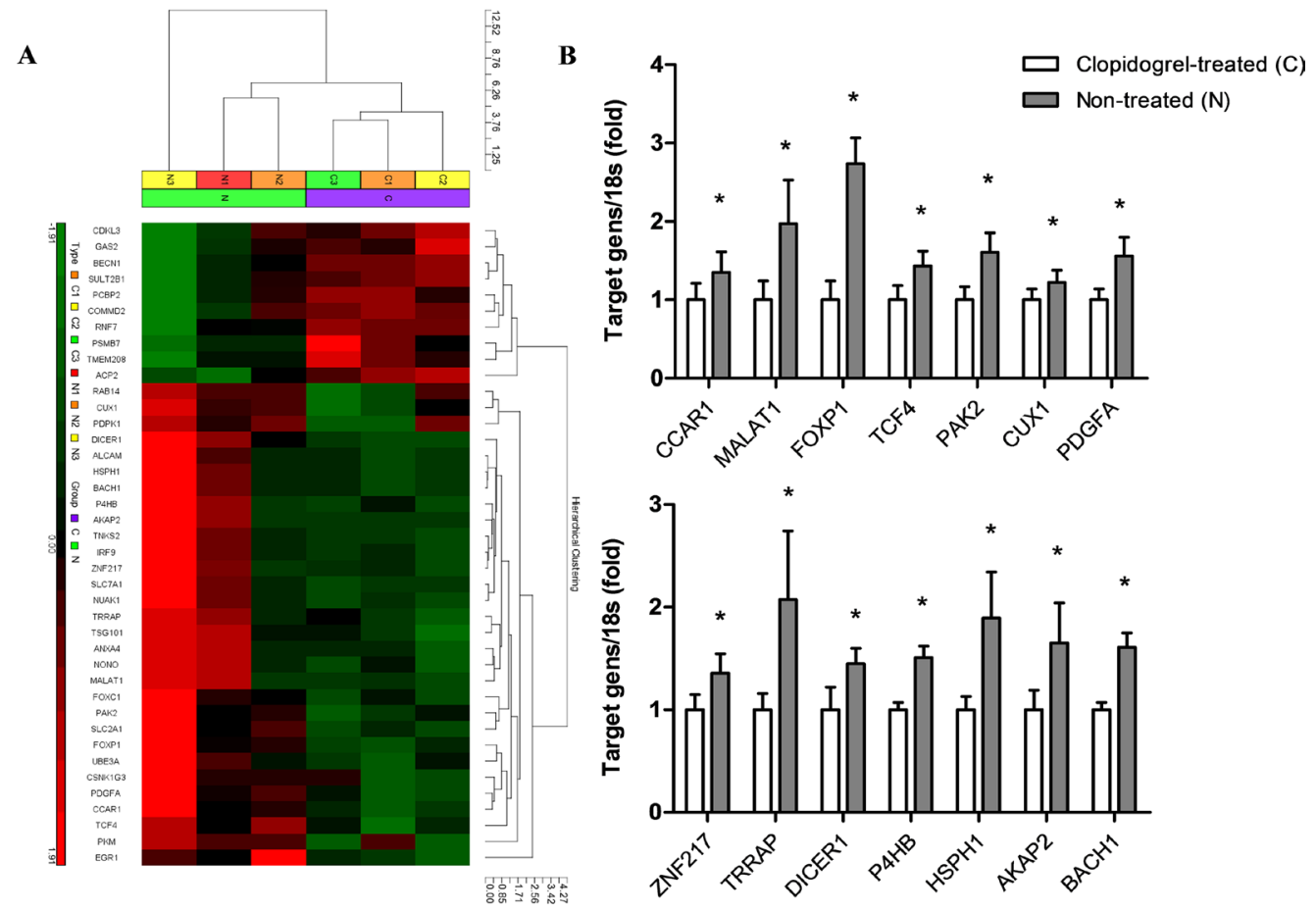

Figure 6: Microarray analysis in xenograft tumors from control and clopidogrel-treated mice. An unbiased microarray expression profiling heat map between control and clopidogrel-treated mice was shown. High and low expression were indicated in red and green, respectively A. mRNA levels of 14 candidate genes in mouse tumor samples were verified with real-time PCR B. $* P<0.05$ vs. clopidogrel-treated.

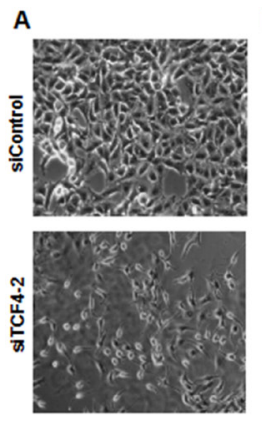

B

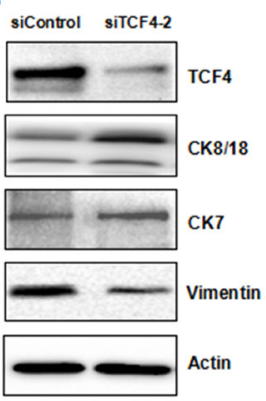

C

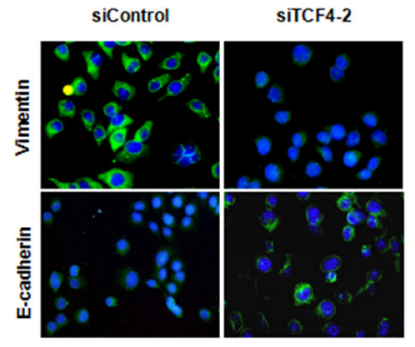

D

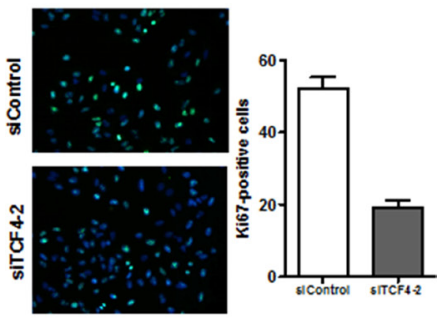

E

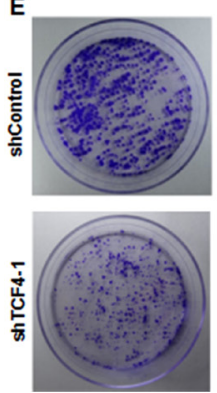

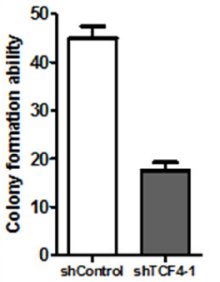

$\mathbf{F}$

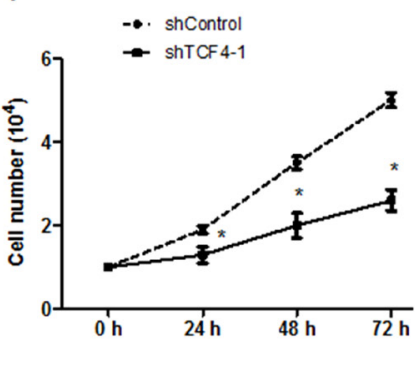

G

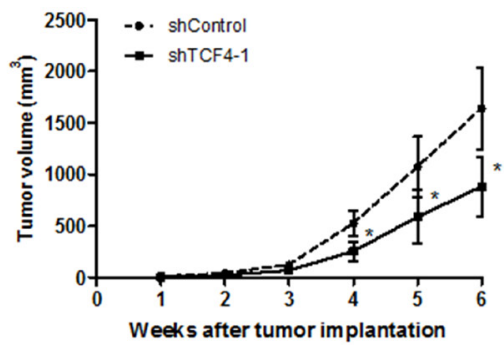

Figure 7: TCF4 knockdown induced cell differentiation and decreased tumorigenicity. Phase contrast images of HepG-2 cells transfected with either siControl or siTC4 A. Differentiation marker expression was analyzed by western blotting B. or IF C. Cell proliferation was assessed by Ki-67 IF staining D., proliferation assay E. and colony formation assay F. ShTCF4- or shControl-transfected cells were injected into NOD/SCID mice subcutaneously and tumor volumes were recorded $\mathbf{G} .{ }^{*} P<0.05$ vs. control. 
as CCAR1, MALAT1, FOXP1, TCF4 and CUX1 were previously reported as highly expressed in HCC [52-56]. We demonstrated that TCF4 was a pivotal differentiation regulator in hepatoma cells, and TCF4 repression promoted HepG-2 cell differentiation and inhibited tumor formation. How platelet-tumor cell binding enhances TCF4 expression in hepatoma cells needs further investigation.

In conclusion, we found that platelets were highly activated in poorly differentiated HCC. Accumulation of activated platelets in HCC tissues induced platelettumor cell binding. Clopidogrel effectively inhibited platelet-tumor cell binding and promoted hepatoma cell differentiation. These results identify platelets as potential key regulators in $\mathrm{HCC}$ differentiation, supporting the use of anti-platelet therapy in cancer patients. Clopidogrel, as a common, inexpensive and safe intervention might constitute an effective adjuvant to chemotherapy or radiotherapy for both tumor inhibition and thrombosis prevention in HCC.

\section{MATERIALS AND METHODS}

\section{Patient characteristics}

We retrospectively analyzed 100 histologically diagnosed HCC patients who received a partial hepatectomy between January 2009 and December 2014 at the First Affiliated Hospital of Dalian Medical University. Patients with conditions that might affect platelet parameters, such as diabetes mellitus, cardiovascular diseases and anti-platelet drug use, were excluded from the study. Routine hematological assays examined prior to surgery were recorded. Fresh blood samples were obtained from $24 \mathrm{HCC}$ patients prior to surgery and 8 healthy controls. Experimental protocols were approved by the ethics committee of the First Affiliated Hospital of Dalian Medical University.

\section{Determination of P-selectin positive platelets in human and mouse}

Human venous blood samples were collected into a standardized tube containing EDTA as anticoagulant. Mouse blood was collected by cardiac puncture. To obtain platelet-rich plasma (PRP), blood $(1 \mathrm{ml})$ was mixed with $300 \mu$ lof platelet washing buffer $(\mathrm{pH} 6.5,4.3 \mathrm{mM}$ $\mathrm{K}_{2} \mathrm{HPO}_{4}, 4.3 \mathrm{mM} \mathrm{Na} \mathrm{HPO}_{4}, 24.3 \mathrm{mM} \mathrm{NaH} \mathrm{PO}_{4}, 113 \mathrm{mM}$ $\mathrm{NaCl}, 5.5 \mathrm{mM}$ glucose, $0.5 \%$ bovine serum albumin, $10 \mathrm{mM}$ theophylline) and then centrifuged at $250 \mathrm{~g}$ for $2 \mathrm{~min}$. Platelet pellets from PRP were collected by centrifugation at 2,000 $\mathrm{g}$ for $2 \mathrm{~min}$ and re-suspended in $1 \%$ fetal bovine serum (FBS) in PBS for flow cytometry. P-selectin antibody or isotype control (FITC-conjugated, BD Biosciences) was added to $10 \mu \mathrm{l}$ of PRP and incubated for $30 \mathrm{~min}$ in darkness. P-selectin positive platelets were recorded and analyzed with a Becton-Dickinson FACSCalibur flow cytometer with FlowJo software.

\section{Assay for adenosine diphosphate (ADP) in plasma}

ADP levels in patient and mouse plasma samples were determined using the ADP-GloTM Kinase Assay kit (Promega) following the supplier's instructions.

\section{Cell culture}

The human hepatoma cell line, HepG-2, was obtained from the Shanghai Cell Bank. Cells were maintained in DMEM (Gibco, high glucose) containing $10 \%$ FBS (Gibco) and cultured in a humidified $5 \% \mathrm{CO}_{2}$ atmosphere at $37^{\circ} \mathrm{C}$.

\section{Mouse xenograft assay and anti-platelet intervention}

Six-week-old NOD/SCID mice were obtained from the animal center of Dalian Medical University and were maintained under specific pathogen free conditions. Mouse care and use protocols were approved by the Animal Committee of Dalian Medical University in accordance with national guidelines. HepG-2 cells $\left(1 \times 10^{6}\right)$ were subcutaneously injected into the right flank. After transplantation, body weight and tumor size were measured every two days. For anti-platelet treatment, mice were randomly assigned into two groups and one group received clopidogrel treatment after three weeks transplantation. Tablets containing clopidogrel $(75 \mathrm{mg})$ were ground into fine powder, freshly emulsified in $0.5 \%$ methyl cellulose solution and administered by gavage. A loading dose of $15 \mathrm{mg} / \mathrm{kg}$ was given at the first day of treatment, followed by the maintenance dose of $5 \mathrm{mg} /$ $\mathrm{kg}$ once daily for the remainder of the three weeks [57]. The non-treated group was given $0.5 \%$ methyl cellulose solution by gavage.

\section{Bleeding time measurement}

Inhibition of platelet activity by clopidogrel was tested by measuring tail bleeding time as previously reported [57]. Both treated and non-treated mice were subjected to bleeding time measurements. Sterile saline was poured into a $50 \mathrm{ml}$ test tube and heated in a $37^{\circ} \mathrm{C}$ water bath for $1 \mathrm{~h}$. A $10-\mathrm{mm}$ segment of the tail tip was cut off and the tip of the tail was immersed in pre-warmed saline. Bleeding time was defined as the period of time where there was a clearly visible stream of blood that was continuously flowing.

\section{Western blotting}

Mice were euthanized by an overdose of pentobarbital (100 mg/kg, intraperitoneal injection) after 6 weeks of transplantation. Tumors were removed and volumes were recorded. Western blotting was performed 
with primary antibodies for vimentin (1/500, Abcam), CK8/18 (1/1000, Cell signaling) and CK7 (1/2000, Cell signaling). Membranes were re-probed with $\beta$-actin to verity loading consistency.

\section{Immunofluorescence}

Cells were seeded on poly-lysine pre-coated cover slides, fixed in $4 \%$ paraformaldehyde at room temperature for $20 \mathrm{~min}$ and then permeabilized in 1\% Triton-X 100 for $10 \mathrm{~min}$. After blocking in 5\% of BSA, slides were incubated with primary antibody overnight at $4^{\circ} \mathrm{C}$, followed by secondary antibody conjugated with Alex-488 for $30 \mathrm{~min}$. Nuclei were stained with DAPI.

\section{Immunohistochemistry}

IHC was used to determine the contents of platelets (CD41) or hepatocyte specific antigen (heppar-1) expression in tumor sections. Paraffin-embedded HCC tissue samples or mouse xenograft tumors were cut at a thickness of $5 \mu \mathrm{m}$ and then mounted on coated microscope slides. Briefly, antigen retrieval was conducted by slide immersion in citrate-EDTA buffer followed by $5 \mathrm{~min}$ in a microwave oven at high power. Non-specific staining was blocked using $10 \%$ goat serum. After blocking, 50 $\mu 1$ of primary antibody (CD41, BD biosciences; heppar-1, Novus) was applied to each section for $1 \mathrm{~h}$. A mouse IgG isotype control antibody (Jackson ImmunoResearch) was used at the same concentration as primary antibodies. After incubation with secondary antibody, sections were incubated with DAB until the desired staining developed. Sections were then counterstained with Myer's hematoxylin for $2 \mathrm{~min}$, then dehydrated and mounted with DePex.

\section{Detection of platelet-tumor cell binding in tissues and cell culture}

To assess conjugation between platelets and hepatoma cells, platelet marker CD41 positive tumor cells were measured in both cell culture and tumor samples using flow cytometry. Tissues from HCC patients and mice were mechanically dissociated using a scalpel, transferred to DMEM containing 1:1 collagenase I (3 mg/ $\mathrm{mL})$ :hyaluronidase (100 U/mL; Sigma) and incubated at $37^{\circ} \mathrm{C}$ for $2 \mathrm{~h}$ on a shaking incubator. After filtration through a $40-\mu \mathrm{m}$ filter, specimens were dissociated into single cells and washed with PBS several times. Cells were plated in DMEM with 10\% FBS. After $2 \mathrm{~h}$, fibroblasts were adhered. Un-adhered cells were collected by centrifugation and re-suspended in FACS buffer. Cells from human HCC tissues were incubated with anti-human CD41 (FITC-conjugated, BD Biosciences), anti-human CD45 (PE-conjugated, BD Biosciences) and anti-human CD31 (Alex Fluor 647-conjugated, BD Biosciences) for 30 min in darkness. Cells obtained from mice tumor specimens were incubated with anti-mouse CD41 (FITCconjugated, BD Biosciences), anti-mouse CD45 (PEconjugated, BD Biosciences) and anti-mouse CD31 (APCconjugated, BD Biosciences). CD45 and CD31 antibodies were used to exclude leukocytes and endothelial cells in tissue samples.

Washed platelets from HCC patients and healthy controls were extracted as previously described. HepG-2 cells were co-cultured with platelets at 1:100 for $24 \mathrm{~h}$ [27]. P-selectin blocking antibody ( $25 \mu \mathrm{g} / \mathrm{ml}, \mathrm{R} \& \mathrm{D}$ system) or IgG control antibody (BD Biosciences) was added to the co-culture. After $24 \mathrm{~h}$, cells were harvested. re-suspended in FACS buffer and then incubated with anti-human CD41 antibody (FITC-conjugated, BD Biosciences). Cells were thoroughly washed and then analyzed using a FACSCalibur flow cytometer. Analysis was performed using FlowJo software. The percentage of CD41 positive cells in total hepatoma cells was determined.

\section{Microarray assay and comprehensive bioinformatics analysis}

Total RNA was isolated with TRIzol (Invitrogen) according to the manufacturer's instructions. Gene expression profiling was performed using the Human Genome UI33 plus 2.0 array according to the manufacturer's instructions (Affymetrix). Fifteen micrograms of complementary RNA was fractionated and hybridized to an Affymetrix GeneChip.

\section{Validation of microarray data by qPCR analysis}

Quantitative real-time PCR (qPCR) was used to verify the differential expression of 14 selected genes that were detected by microarray. These genes included CCAR1, MALAT1, FOXP1, TCF4, PAK2, CUX1, TRRAP, PDGFA, ZNF217, DICER1, P4HB, HSPH1 and AKAP2. qPCR analysis was performed with a 7500 system, and primers are listed in Table 2. Cycling conditions included an initial, 5 min cycle at $95^{\circ} \mathrm{C}$, followed by 40 cycles of $30 \mathrm{sec}$ at $95^{\circ} \mathrm{C}, 30 \mathrm{sec}$ at $54^{\circ} \mathrm{C}$, and $15 \mathrm{sec}$ at $72^{\circ} \mathrm{C}$. Gene expression was quantified relative to $18 \mathrm{~S}$ expression.

\section{Small interfering RNA transfection}

RNA oligonucleotide double strands to target TCF4 were synthesized by GenePharma (siRNA-TCF4-1, 5'-CGAAAGUUUCCGAGACAAATT-3'; siRNA-TCF4-2, 5'-GAACCUAUCUCCAGAUGAATT-3'; siRNA-TCF4-3, 5'-GGAUUUAGCUGAUGUCAAATT-3'). Cells were seeded into six-well plates $24 \mathrm{~h}$ before transfection, with serum deprivation $1 \mathrm{~h}$ before transfection. In each well, 50 $\mathrm{nM}$ of siRNA and $5 \mu \mathrm{l}$ of Lipofectamine 2000 (Invitrogen) were mixed in Opti-MEM (Gibco) and then added to cells. After $6 \mathrm{~h}$ of transfection, serum-free medium was replaced 
Table 2: Real-time PCR primers

\begin{tabular}{|c|c|c|}
\hline Gene & & Primer \\
\hline \multirow[t]{2}{*}{$18 \mathrm{~s}$} & Forward & 5'-TTGACGGGAAGGGCACCACCAG-3' \\
\hline & Reverse & 5'-GCACCACCACCCACGGAATCG-3' \\
\hline \multirow[t]{2}{*}{ CCAR1 } & Forward & 5'-TCTCCCGAGGATACAAGCA-3' \\
\hline & Reverse & 5'-GACCAATGGGTAGGTGTAGAAA-3' \\
\hline \multirow[t]{2}{*}{ MALAT1 } & Forward & 5'-CAGACCACCACAGGTTTACAGT-3' \\
\hline & Reverse & 5'-GACCATCCCAAAATGCTTCA-3' \\
\hline \multirow[t]{2}{*}{ FOXP1 } & Forward & 5'-TCTCATAAACCATCAGCCCTCT-3' \\
\hline & Reverse & 5'-CCACTCATCTTCGTCTCAGCA-3' \\
\hline \multirow[t]{2}{*}{ TCF4 } & Forward & 5'-ACAGAAAGGGGCTCATACTCA-3' \\
\hline & Reverse & 5'-CGAAAGGGTTCCTGGGTT-3' \\
\hline \multirow[t]{2}{*}{ PAK2 } & Forward & 5'-CTTTTGGGAATGGAAGGATC-3' \\
\hline & Reverse & 5'-GCTTTCCGTGTAACCACCTCT-3' \\
\hline \multirow[t]{2}{*}{ CUX1 } & Forward & 5'-CAGGCTGACTATGAAGAGGTGA-3' \\
\hline & Reverse & 5'-AGGTCGCTGTTGGAGATGC-3' \\
\hline \multirow[t]{2}{*}{ PDGFA } & Forward & 5'-GATACCTCGCCCATGTTCTG-3' \\
\hline & Reverse & 5'-TCAGGCTGGTGTCCAAAGA-3' \\
\hline \multirow[t]{2}{*}{ ZNF217 } & Forward & 5'-CGCTGTTGTTCCATTCCG-3' \\
\hline & Reverse & 5'-CTGGTTCACAGAGGGTAGGC-3' \\
\hline \multirow[t]{2}{*}{ TRRAP } & Forward & 5'-CGACTTCCTCTACGACCACAT-3' \\
\hline & Reverse & 5'-CGACTCCTTCAGCATCTTCC-3' \\
\hline \multirow[t]{2}{*}{ DICER1 } & Forward & 5'-CAGAACAGCATCCGCCACA-3' \\
\hline & Reverse & 5'-GCCTGTCCTTCTCCTCCTTGT-3' \\
\hline \multirow[t]{2}{*}{$\mathrm{P} 4 \mathrm{HB}$} & Forward & 5'-TGCAAACAGTTGGCTCCC-3' \\
\hline & Reverse & 5'-TGCGTTCCCCGTTGTAATC-3' \\
\hline \multirow[t]{2}{*}{ HSPH1 } & Forward & 5'-GAAAACAGCCTCAAGAAACCAG-3' \\
\hline & Reverse & 5'-CCGTAATTCAAAGCAACAGC-3' \\
\hline \multirow[t]{2}{*}{ AKAP2 } & Forward & 5'-CACTGACTAATCCGAGACCACC-3' \\
\hline & Reverse & 5'-TTAGAAGGCTCGCTGTAGGG-3' \\
\hline \multirow[t]{2}{*}{ BACH1 } & Forward & 5'-CACTGACTAATCCGAGACCACC-3' \\
\hline & Reverse & 5'-GAGTCGTCTCCCAAGCTAATG-3' \\
\hline
\end{tabular}

with medium containing $10 \%$ of FBS. RNAi efficiency was determined by western blotting at $48 \mathrm{~h}$.

\section{Short-hairpin RNA transfection}

shRNA constructs targeting TCF4 (shRNATCF4-1, CCGGGCAGACATCAATTCCAGTCTTC TCGAGAAGACTGGAATTGATGTCTGCTTTTT; shRNA-TCF4-2, CCGGCGAATTGAAGATCGTTTA
GAACTCGAGTTCTAAACGATCTTCAATTCGTTT TT) were inserted into the pGPU6/GFP/Neo plasmid (GenePharma). HepG-2 cells were grown to $80 \%$ confluence prior to transfection. In each well, $4 \mu \mathrm{g}$ of plasmid DNA and $10 \mu \mathrm{l}$ of Lipofectamine 2000 (Invitrogen) were mixed in Opti-MEM (Gibco) and then added to cells. Medium was replaced $6 \mathrm{~h}$ posttransfection. Cells were selected with G418 $(800 \mu \mathrm{g} / \mathrm{ml})$. 
A non-target plasmid containing an shRNA that does not target human genes was used as a control.

\section{Cell proliferation assay}

Cell proliferation was measured by cell number counting assay. We seeded 10,000 shControl- or shTCF4transfected cells into a 24-well plate and counted for three continuous days to monitor cell growth.

\section{Colony formation assay}

Approximately 1000 shControl- or shTCF4transfected cells were seeded into 6-well plates in duplicate and incubated for 12 days. Cells were then fixed and stained with $0.4 \%$ crystal violet for $10 \mathrm{~min}$ at room temperature, and colonies were counted.

\section{Statistical analyses}

Results are expressed as means \pm SEM unless otherwise stated. ANOVAs followed by multiple comparison tests were performed using GraphPad Prism software. $P<0.05$ was considered statistically significant.

\section{CONFLICTS OF INTEREST}

The authors declare no conflicts of interest.

\section{GRANT SUPPORT}

This study was supported by grants from the National Nature Science Foundation of China (No. 81201656 to $\mathrm{YL}$ ), the Nature Science Foundation of Liaoning Province (No. 2015020252 to Y Zhao) and the Dalian Municipal Science and Technology Plan Project (No. 2015E12SF148 to Y Zhao).

\section{REFERENCES}

1. El-Serag HB. Hepatocellular carcinoma. N Engl J Med. 2011; 365:1118-1127.

2. Sugimachi K, Maehara S, Tanaka S, Shimada M. Repeat hepatectomy is the most useful treatment for recurrent hepatocellular carcinoma. J Hepatobiliary Pancreat Surg. 2001; 8:410-416.

3. Yamamoto J, Kosuge T, Takayama T, Shimada K, Yamasaki S, Ozaki H, Yamaguchi N, Makuuchi M. Recurrence of hepatocellular carcinoma after surgery. Br J Surg. 1996; 83:1219-1222.

4. Nakai S, Masaki T, Shiratori Y, Ohgi T, Morishita A, Kurokohchi K, Watanabe S, Kuriyama S. Expression of p57(kip2) in hepatocellular carcinoma: Relationship between tumor differentiation and patient survival. Int $\mathrm{J}$ Oncol. 2002; 20:769-775.
5. Schoniger-Hekele M, Hanel S, Wrba F, Muller C. Hepatocellular carcinoma-survival and clinical characteristics in relation to various histologic molecular markers in western patients. Liver Int. 2005; 25:62-69.

6. Zavaglia C, De Carlis L, Alberti AB, Minola E, Belli LS, Slim AO, Airoldi A, Giacomoni A, Rondinara G, Tinelli C, Forti D, Pinzello G. Predictors of long-term survival after liver transplantation for hepatocellular carcinoma. Am J Gastroenterol. 2005; 100:2708-2716.

7. Jang HJ, Kim TK, Burns PN, Wilson SR. Enhancement patterns of hepatocellular carcinoma at contrast-enhanced us: Comparison with histologic differentiation. Radiology. 2007; 244:898-906.

8. Pecchi A, Besutti G, De Santis M, Del Giovane C, Nosseir S, Tarantino G, Di Benedetto F, Torricelli P. Posttransplantation hepatocellular carcinoma recurrence: Patterns and relation between vascularity and differentiation degree. World J Hepatol. 2015; 7:276-284.

9. Cheung TK, Lai CL, Wong BC, Fung J, Yuen MF. Clinical features, biochemical parameters, and virological profiles of patients with hepatocellular carcinoma in hong kong. Aliment Pharmacol Ther. 2006; 24:573-583.

10. Llovet JM, Bustamante J, Castells A, Vilana R, Ayuso Mdel C, Sala M, Bru C, Rodes J, Bruix J. Natural history of untreated nonsurgical hepatocellular carcinoma: Rationale for the design and evaluation of therapeutic trials. Hepatology. 1999; 29:62-67.

11. Minagawa M, Makuuchi M. Treatment of hepatocellular carcinoma accompanied by portal vein tumor thrombus. World J Gastroenterol. 2006; 12:7561-7567.

12. Schoniger-Hekele M, Muller C, Kutilek M, Oesterreicher C, Ferenci P, Gangl A. Hepatocellular carcinoma in central europe: Prognostic features and survival. Gut. 2001; 48:103-109.

13. Kurt M, Onal IK, Sayilir AY, Beyazit Y, Oztas E, Kekilli M, Turhan N, Karaman K, Akdogan M. The role of mean platelet volume in the diagnosis of hepatocellular carcinoma in patients with chronic liver disease. Hepatogastroenterology. 2012; 59:1580-1582.

14. Karaman K, Bostanci EB, Aksoy E, Kurt M, Celep B, Ulas M, Dalgic T, Surmelioglu A, Hayran M, Akoglu M. The predictive value of mean platelet volume in differential diagnosis of non-functional pancreatic neuroendocrine tumors from pancreatic adenocarcinomas. Eur J Intern Med. 2011; 22:e95-98.

15. Osada J, Rusak M, Kamocki Z, Dabrowska MI, Kedra B. Platelet activation in patients with advanced gastric cancer. Neoplasma. 2010; 57:145-150.

16. Li JY, Li Y, Jiang Z, Wang RT, Wang XS. Elevated mean platelet volume is associated with presence of colon cancer. Asian Pac J Cancer Prev. 2014; 15:10501-10504.

17. Gay LJ, Felding-Habermann B. Contribution of platelets to tumor metastasis. Nat Rev Cancer. 2011; 11:123-134. 
18. Machlus KR, Italiano JE, Jr. The incredible journey: From megakaryocyte development to platelet formation. J Cell Biol. 2013; 201:785-796.

19. Thon JN, Italiano JE, Jr. Does size matter in platelet production? Blood. 2012; 120:1552-1561.

20. Jackson SR, Carter JM. Platelet volume: Laboratory measurement and clinical application. Blood Rev. 1993; 7:104-113.

21. Leader A, Pereg D, Lishner M. Are platelet volume indices of clinical use? A multidisciplinary review. Ann Med. 2012; 44:805-816.

22. Belloc C, Lu H, Soria C, Fridman R, Legrand Y, Menashi $\mathrm{S}$. The effect of platelets on invasiveness and protease production of human mammary tumor cells. Int J Cancer. 1995; 60:413-417.

23. Huang S, Van Arsdall M, Tedjarati S, McCarty M, Wu W, Langley R, Fidler IJ. Contributions of stromal metalloproteinase-9 to angiogenesis and growth of human ovarian carcinoma in mice. J Natl Cancer Inst. 2002; 94:1134-1142.

24. Mannori G, Crottet P, Cecconi O, Hanasaki K, Aruffo A, Nelson RM, Varki A, Bevilacqua MP. Differential colon cancer cell adhesion to e-, p-, and 1-selectin: Role of mucintype glycoproteins. Cancer Res. 1995; 55:4425-4431.

25. Coupland LA, Parish CR. Platelets, selectins, and the control of tumor metastasis. Semin Oncol. 2014; 41:422-434.

26. Qi C, Wei B, Zhou W, Yang Y, Li B, Guo S, Li J, Ye J, Li J, Zhang Q, Lan T, He X, Cao L, Zhou J, Geng J, Wang L. P-Selectin-Mediated Platelet Adhesion Promotes Tumor Growth. Oncotarget. 2015; 6:6584-96. doi: 10.18632/ oncotarget.3164.

27. Dovizio M, Maier TJ, Alberti S, Di Francesco L, Marcantoni E, Munch G, John CM, Suess B, Sgambato A, Steinhilber D, Patrignani P. Pharmacological inhibition of platelet-tumor cell cross-talk prevents platelet-induced overexpression of cyclooxygenase- 2 in ht29 human colon carcinoma cells. Mol Pharmacol. 2013; 84:25-40.

28. Labelle M, Begum S, Hynes RO. Direct signaling between platelets and cancer cells induces an epithelialmesenchymal-like transition and promotes metastasis. Cancer Cell. 2011; 20:576-590

29. Qi CL, Wei B, Ye J, Yang Y, Li B, Zhang QQ, Li JC, He XD, Lan T, Wang LJ. P-selectin-mediated platelet adhesion promotes the metastasis of murine melanoma cells. PloS one. 2014; 9:e91320

30. Ludwig RJ, Boehme B, Podda M, Henschler R, Jager E, Tandi C, Boehncke WH, Zollner TM, Kaufmann R, Gille J. Endothelial p-selectin as a target of heparin action in experimental melanoma lung metastasis. Cancer Res. 2004; 64:2743-2750.

31. Stone JP, Wagner DD. P-selectin mediates adhesion of platelets to neuroblastoma and small cell lung cancer. J Clin Invest. 1993; 92:804-813.
32. Jin J, Kunapuli SP. Coactivation of two different $g$ protein-coupled receptors is essential for adp-induced platelet aggregation. Proc Natl Acad Sci U S A. 1998; 95:8070-8074.

33. Nurden AT, Nurden P. Advantages of fast-acting adp receptor blockade in ischemic heart disease. Arterioscler Thromb Vasc Biol. 2003; 23:158-159.

34. Boukerche H, Berthier-Vergnes O, Penin F, Tabone E, Lizard G, Bailly M, McGregor JL. Human melanoma cell lines differ in their capacity to release adp and aggregate platelets. Br J Haematol. 1994; 87:763-772.

35. Bastida E, Escolar G, Almirall L, Ordinas A. Platelet activation induced by a human neuroblastoma tumor cell line is reduced by prior administration of ticlopidine. Thromb Haemost. 1986; 55:333-337.

36. Uluckan O, Eagleton MC, Floyd DH, Morgan EA, Hirbe AC, Kramer M, Dowland N, Prior JL, Piwnica-Worms D, Jeong SS, Chen R, Weilbaecher K. Apt102, a novel adpase, cooperates with aspirin to disrupt bone metastasis in mice. J Cell Biochem. 2008; 104:1311-1323.

37. Nguyen VT, Law MG, Dore GJ. Hepatitis b-related hepatocellular carcinoma: Epidemiological characteristics and disease burden. J Viral Hepat. 2009; 16:453-463.

38. Sitia G, Aiolfi R, Di Lucia P, Mainetti M, Fiocchi A, Mingozzi F, Esposito A, Ruggeri ZM, Chisari FV, Iannacone M, Guidotti LG. Antiplatelet therapy prevents hepatocellular carcinoma and improves survival in a mouse model of chronic hepatitis b. Proc Natl Acad Sci U S A. 2012; 109:E2165-2172.

39. $\mathrm{Ng} \mathrm{K}$, Meyerhardt JA, Chan AT, Sato K, Chan JA, Niedzwiecki D, Saltz LB, Mayer RJ, Benson AB, 3rd, Schaefer PL, Whittom R, Hantel A, Goldberg RM, Venook AP, Ogino S, Giovannucci EL, Fuchs CS. Aspirin and cox-2 inhibitor use in patients with stage iii colon cancer. J Natl Cancer Inst. 2015; 107:345.

40. Holmes MD, Chen WY, Li L, Hertzmark E, Spiegelman D, Hankinson SE. Aspirin intake and survival after breast cancer. J Clin Oncol. 2010; 28:1467-1472.

41. Fontaine E, McShane J, Page R, Shackcloth M, Mediratta N, Carr M, Soorae A, Poullis M. Aspirin and non-small cell lung cancer resections: Effect on long-term survival. Eur J Cardiothorac Surg. 2010; 38:21-26.

42. Holmes CE, Huang JC, Pace TR, Howard AB, Muss HB. Tamoxifen and aromatase inhibitors differentially affect vascular endothelial growth factor and endostatin levels in women with breast cancer. Clin Cancer Res. 2008; 14:3070-3076.

43. Holmes CE, Jasielec J, Levis JE, Skelly J, Muss HB. Initiation of aspirin therapy modulates angiogenic protein levels in women with breast cancer receiving tamoxifen therapy. Clin Transl Sci. 2013; 6:386-390.

44. Choe KS, Correa D, Jani AB, Liauw SL. The use of anticoagulants improves biochemical control of localized 
prostate cancer treated with radiotherapy. Cancer. 2010; 116:1820-1826.

45. Amirkhosravi A, Amaya M, Siddiqui F, Biggerstaff JP, Meyer TV, Francis JL. Blockade of gpiib/iiia inhibits the release of vascular endothelial growth factor (vegf) from tumor cell-activated platelets and experimental metastasis. Platelets. 1999; 10:285-292.

46. Trikha M, Zhou Z, Timar J, Raso E, Kennel M, Emmell E, Nakada MT. Multiple roles for platelet gpiib/iiia and alphavbeta3 integrins in tumor growth, angiogenesis, and metastasis. Cancer Res. 2002; 62:2824-2833.

47. Erpenbeck L, Nieswandt B, Schon M, Pozgajova M, Schon MP. Inhibition of platelet gpib alpha and promotion of melanoma metastasis. J Invest Dermatol. 2010; 130:576-586.

48. Jain S, Zuka M, Liu J, Russell S, Dent J, Guerrero JA, Forsyth J, Maruszak B, Gartner TK, Felding-Habermann B, Ware J. Platelet glycoprotein ib alpha supports experimental lung metastasis. Proc Natl Acad Sci U S A. 2007; 104:9024-9028.

49. Jain S, Russell S, Ware J. Platelet glycoprotein vi facilitates experimental lung metastasis in syngenic mouse models. J Thromb Haemost. 2009; 7:1713-1717.

50. Mezouar S, Darbousset R, Dignat-George F, PanicotDubois L, Dubois C. Inhibition of platelet activation prevents the p-selectin and integrin-dependent accumulation of cancer cell microparticles and reduces tumor growth and metastasis in vivo. Int J Cancer. 2015; 136:462-475.

51. Chiodoni C, Iezzi M, Guiducci C, Sangaletti S, Alessandrini I, Ratti C, Tiboni F, Musiani P, Granger DN, Colombo MP.
Triggering cd40 on endothelial cells contributes to tumor growth. J Exp Med. 2006; 203:2441-2450.

52. Ha SY, Kim JH, Yang JW, Kim J, Kim B, Park CK. The overexpression of ccar1 in hepatocellular carcinoma associates with poor prognosis. Cancer Res Treat. 2015.

53. Ou CY, Kim JH, Yang CK, Stallcup MR. Requirement of cell cycle and apoptosis regulator 1 for target gene activation by wnt and beta-catenin and for anchorageindependent growth of human colon carcinoma cells. J Biol Chem. 2009; 284:20629-20637.

54. Konishi H, Ichikawa D, Yamamoto Y, Arita T, Shoda K, Hiramoto H, Hamada J, Itoh H, Fujita Y, Komatsu $\mathrm{S}$, Shiozaki A, Ikoma H, Ochiai T, Otsuji E. Plasma malat1 level is associated with liver damage and predicts development of hepatocellular carcinoma. Cancer Sci. 2015.

55. Zhang Y, Zhang S, Wang X, Liu J, Yang L, He S, Chen L, Huang J. Prognostic significance of foxp1 as an oncogene in hepatocellular carcinoma. J Clin Pathol. 2012; 65:528-533.

56. Walker MP, Stopford CM, Cederlund M, Fang F, Jahn C, Rabinowitz AD, Goldfarb D, Graham DM, Yan F, Deal AM, Fedoriw Y, Richards KL, Davis IJ, Weidinger G, Damania B, Major MB. Foxp1 potentiates wnt/beta-catenin signaling in diffuse large b cell lymphoma. Sci Signal. 2015; 8:ra12.

57. Liu Y, Gao XM, Fang L, Jennings NL, Su Y, Q X, Samson AL, Kiriazis H, Wang XF, Shan L, Sturgeon SA, Medcalf RL, Jackson SP, Dart AM, Du XJ. Novel role of platelets in mediating inflammatory responses and ventricular rupture or remodeling following myocardial infarction. Arterioscler Thromb Vasc Biol. 2011; 31:834-841. 